\title{
Action of cardosin A from Cynara humilis on ovine and caprine caseinates
}

\author{
BY SOFIA $V$. SILVA AND F. XAVIER MALCATA* \\ Escola Superior de Biotecnologia, Unicersidade Católica Portuguesa, Rua Dr António \\ Bernardino de Almeida, P-4200-072 Porto, Portugal
}

(Received 6 May 1999 and accepted for publication 27 January 2000)

In the Iberian Peninsula, the proteinases present in the flowers of members of the Cynara genus, C. cardunculus, $C$. humilis and $C$. scolymus, have for many years been successfully used in the manufacture of traditional cheeses from ovine and/or caprine milk on individual farms (Vieira de Sá \& Barbosa, 1972; Trujillo et al. 1994). In Portugal, $C$. cardunculus is the species most frequently employed. Although commercial thistle was tentatively assumed to be pure in taxonomic terms, accurate analyses have shown that the flowers of $C$. cardunculus are often mixed with flowers of $C$. humilis (Pires et al. 1994). The clotting activity of $C$. humilis is due to an aspartic proteinase, currently designated cardosin $\mathrm{A}$ and similar to another enzyme obtained from $C$. cardunculus. This enzyme is similar in specificity and activity to chymosin (Pires et al. 1994).

The action of cardosin A from C. cardunculus upon ovine and caprine caseins has been reported recently (Ramalho-Santos et al. 1996; Simões, 1998; Sousa \& Malcata, 1998), but as yet there is no information on the proteolytic activity of the proteinase from $C$. humilis upon caseins from milks other than bovine. Caseins from small ruminants' milks are the usual substrates of cardosin during milk coagulation and cheese ripening, and sodium caseinate represents an intermediate system between isolated caseins and the cheese matrix that is free from interference by fat. Thus ovine and caprine caseinates may be useful substrates for investigating the proteolytic activity of cardosin.

The aim of the present study was to compare the action of pure cardosin $\mathrm{A}$, obtained from $C$. humilis, on caprine and ovine caseinates, and to assess the in vitro contribution of this enzyme to the overall proteolytic action of thistle rennet.

\section{Preparation of substrate}

\section{MATERIALS AND METHODS}

Whole caprine and ovine caseins were prepared by isoelectric precipitation from raw milk at pH $4 \cdot 25$ and $4 \cdot 30$ respectively (Sousa \& Malcata, 1998).

\section{Preparation of enzyme}

Cardosin A was obtained according to the method of Veríssimo et al. (1995), with slight modifications. The first step was gel filtration through a Highload 26/60 Sephacryl S-200 column (Pharmacia. S-751 82 Uppsala, Sweden), equilibrated and eluted with $20 \mathrm{~mm}$-Tris-HCl buffer, $\mathrm{pH} 7 \cdot 6$ at a flow rate of $1.5 \mathrm{ml} / \mathrm{min}$. Purity was 
assayed by SDS-PAGE; in a Phastsystem (Pharmacia) using PhastGel homogeneous 20. Protein concentration was determined by the method of Bradford (Robyt \& White, 1990) using hovine serum albumin (Merck, D-64293 Darmstadt 1, Germany) as standard.

\section{Characterization of cafalytic activity}

Whole (aprine (or oxine) caseinate was dissolved in $100 \mathrm{~mm}$-sodium phosphate buffer, $\mathrm{pH} 65$ at $10 \mathrm{mg} / \mathrm{ml}$. To $10 \mathrm{ml}$ substrate solution. $526 \mu \mathrm{l}$ of an aqueous solution of cardosin $\mathrm{A}(180 \mu \mathrm{g} / \mathrm{ml})$ was added and the mixture was kept at $30^{\circ} \mathrm{C}$ with stirring. Samples were withdrawn after $1 \mathrm{~min}$ and $1,3.6$ and $10 \mathrm{~h}$. The reaction was quenched prior to analysis by electrophoresis by addition of an equal volume of double concentrated Tris-HCl buffer containing urea, 2-mercaptoethanol. Bromophenol blue and EDTA (Mesweeney et al. 1993), and prior to analysis by reversed-phase (RP) HPLC by heating at $95^{\circ} \mathrm{C}$ for $30 \mathrm{~min}$. Two parallel experiments were carried out and analyses run in duplicate.

\section{Quantitative characterization by urea-PAGE}

Urea-PAGE was carried out using a Protean II xi cell vertical slab unit (Bio-Rad Laboratories, Hercules. (A 94547. CSA) according to the Andrews (1983) method ( $\mathrm{pH} 8.9$, separation gel $125 \mathrm{~g} / 1$, stacking gel $40 \mathrm{~g} / 1$ ) with the modifications proposed by Shalabi \& Fox (1987). The gels were stained with Coomassie blue G250 (Bio-Rad) using the method of Blakesley \& Boezi (1977). Quantitation of $\alpha_{\mathrm{s}}$ and $\beta$-caseins was by densitometry using a model GS-700 imaging densitometer (Bio-Rad).

\section{Quantitatice characterization by reversed-phase HPLC}

Samples of hydrolysates $(2 \mathrm{ml})$ were adjusted to $\mathrm{pH} 4 \cdot 6$ by adding $60 \mu \mathrm{l}$ acetic acid $(333 \mathrm{ml} / \mathrm{l})$; after $10 \mathrm{~min}, 60 \mu 1333 \mathrm{M}$-sodium acetate was added. After a further $10 \mathrm{~min}$ the samples were centrifuged at $8000 \mathrm{~g}$ for $10 \mathrm{~min}$ and the supernatants recovered for further analysis. RP-HPLC was performed following the protocol proposed by Singh et al. (1995) with a Beckman system (Beckman Instruments, San Ramon, CA 94583, CSA). A Lichrosorb $250 \times 4 \mathrm{~mm}$ RP-8 $(5 \mu \mathrm{m}$ ) column (Merek) was employed with a Lichrocart $4-4$ guard column (Merck). Elution was at $30^{\circ} \mathrm{C}$ with a flow rate of $1 \mathrm{ml} / \mathrm{min}$ using a mixture of two solvents ( $A$ and $B, 1 \mathrm{ml}$ trifluoroacetic acid $/ 1$ in water and acetonitrile respectively). The elution pattern was: pure $\mathrm{A}$ for $5 \mathrm{~min}$, a linear gradient of $0-500 \mathrm{ml} \mathrm{B} / 1$ over $55 \mathrm{~min}, 500 \mathrm{ml} \mathrm{B} / \mathrm{l}$ for $6 \mathrm{~min}$, a linear gradient to $600 \mathrm{ml} \mathrm{B} / 1$ over $4 \mathrm{~min}$ and $600 \mathrm{ml} \mathrm{B} / \mathrm{l}$ for $3 \mathrm{~min}$. Samples of $100 \mu \mathrm{l}$ were injected on to the column and detection was by measuring absorption at $214 \mathrm{~nm}$.

\section{Qualitative characterization by sequencing}

Peptide-containing peaks were colleeted manually from the outlet of the RP-HPLC system and chemically sequenced, up to at least five residues from the $\mathrm{N}$-terminus, via Edman degradation on an automated pulsed liquid-phase protein-peptide sequencer (model 477 A, Applied Biosystems, Foster City, CA 94404, USA). The partial sequences thus obtained were checked against the (known) sequences of caseins to find which peptide bonds were cleaved.

\section{RESULTS}

The gel filtration step of the aqueous acidic extraction of C. humilis flowers removed low molecular mass contaminants, and further separation by ion-exchange 
(a)
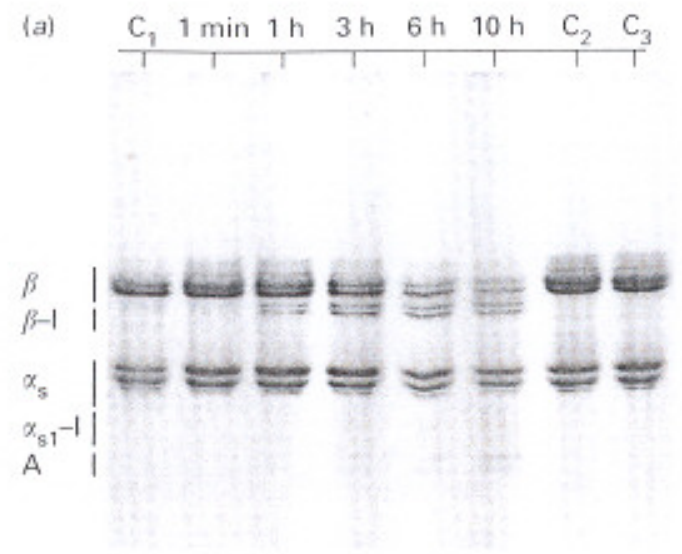

(b)

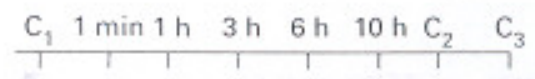

Fig. 1. Crea-PAGE electropherograms of $(a)$ ovine and $(b)$ eaprine sodiam caseinate after hydrolysis by cardosin $A$ for the times indicated. $C_{1} \cdot C_{2}$ and $C_{3}$ were included as controls: $C_{1}$ - untreated ovise for eaprine) sodium caseinate; $C_{2}$ and $C_{3}$ osine for eaprine) sodium caseinate after incubution in the absence of enzyme for $\mathrm{C}_{2}, 1 \mathrm{~min}$ and $\mathrm{C}_{3}, 10 \mathrm{~h}$ respectively. $\beta$. $\beta$-Casein : $\beta$-I. $\beta$-I-casein; $\alpha_{*}, \alpha_{*}$-casein: $\alpha_{s 1}-1, \alpha_{s 1}$-I-casein: A. degradation products of $\alpha_{51}$-I-case-in.

Table 1. Hydrolysis of oxine and caprine $\alpha_{5}$-casein and $\beta$-casein by cardosin $A$

(Values are perentage hydrolysed. means $\pm s D$ for $n=2$ )

\begin{tabular}{|c|c|c|}
\hline Incubation time. min & $x_{s}$-Casein & $\beta$-Caspin \\
\hline \multicolumn{3}{|l|}{ Ovine } \\
\hline 1 & $-7 \pm 0 \cdot 0$ & $3 \cdot 9 \pm 15-1$ \\
\hline (6) & $145 \pm 00$ & $45 \pm 0-1$ \\
\hline 181 & $10-9 \pm 0 \cdot 3$ & $18 \pm 0.2$ \\
\hline 360 & $258 \pm 0.1$ & $39 \cdot 6 \pm 0-1$ \\
\hline 600 & $-29-1 \pm 0-2$ & $52 \cdot 1 \pm 0 \cdot 3$ \\
\hline \multicolumn{3}{|l|}{ Caprine } \\
\hline 1 & $36 \cdot \pm \pm 0 \cdot 1$ & $5 \pm \pi \pm 0 \cdot 2$ \\
\hline 60 & $40 \cdot 2 \pm 0 \cdot 7$ & $8.5-0 \pm 0.3$ \\
\hline 180 & $45.7 \pm 13$ & $86-4 \pm 0 \cdot 5$ \\
\hline 360 & $54 \cdot 5 \pm 0 \cdot 1$ & $86-6 \pm 0 \cdot 1$ \\
\hline 600 & $65.9 \pm 04$ & $86 \cdot 6 \pm 0 \cdot 1$ \\
\hline
\end{tabular}

chromatography produced two peaks, which were taken to be cardosin A (Veríssimo et al. 1995). The purity of these peaks was assayed by SDS-PAGE, which upon molecular mass calibration gave 31 and $15 \mathrm{kDa}$ for the bands corresponding to the two peaks. The fraction corresponding to the second peak eluted was used for the subsequent experiments.

Although both caprine and ovine $\alpha_{\mathrm{s}}$ - and $\beta$-caseins were hydrolysed by cardosin A from $C$. humilis, there were several differences in the peptides produced. Hydrolysis of $\beta$-casein in both caseinates yielded a pair of bands comparable to that of bovine $\beta$-I-casein; they appeared earlier in caprine than in ovine caseinate (Fig. 1). After $10 \mathrm{~h}$ digestion. caprine $\beta$-casein was degraded more extensively than its ovine counterpart (Table 1). The intense degradation of $\alpha_{8}$-casein in caprine caseinate was apparent after $1 \mathrm{~min}$ incubation. and was faster than that of its ovine counterpart (Fig. 1. Table 1). Two bands from ovine caseinate and one from caprine caseinate, which may correspond to bovine $\alpha_{s 1}$-I-casein. became visible just after the $\alpha_{\mathrm{s}}$-casein region (Fig, 1). Two bands ( $\mathrm{A}$ in Fig. 1) with electrophoretic mobilities 


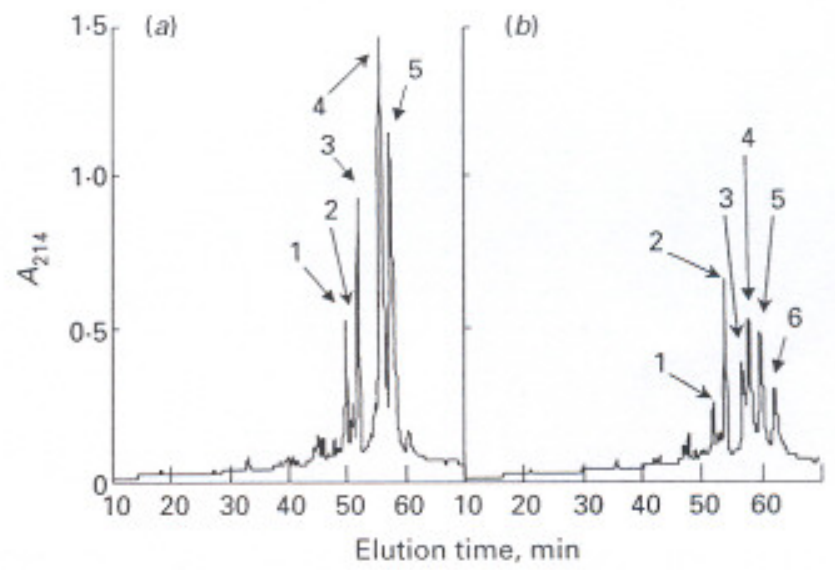

Fig, 2. Rerersed-phase HPLC peptide profile of $(a)$ orine and $(b)$ caprine sodium caseinate after 10 h hydrolysis by cardosin A. For conditions, see text. Peaks 1-5 $(a)$ and 1-6 (b) are identified in Table 2 .

Table 2. Specificity of action of cardosin A upon ovine and caprine caseinates

\begin{tabular}{|c|c|c|c|}
\hline Peak† & Sequence identified & $\begin{array}{l}\text { Source } \\
\text { protein }\end{array}$ & $\begin{array}{l}\text { Peptide bond } \\
\text { cleaved }\end{array}$ \\
\hline \multicolumn{4}{|l|}{ Orine } \\
\hline 1 & $\mathrm{NH}_{2}-\mathrm{Ser}-\mathrm{Gln}-$ Pro-Lys-Val-Leu- & $\beta$-Casein & Leu $^{165}-$ Ser $^{166}$ \\
\hline 2 & $\mathrm{NH}_{z}-$ Tyr-TyT-Len-Pro-Leu- & $\alpha_{s 1}$-Casein & $\operatorname{Trp}^{164-T y r^{165}}$ \\
\hline 3 & $\mathrm{NH}_{2}^{2}$-Tyr-Gin-Glu-Pro-Val- & $\beta$-Casein & Leu ${ }^{190}-\mathrm{Tyr}^{191}$ \\
\hline 4 & $\mathrm{NH}_{-}^{2} \mathrm{Arg}-\mathrm{Glu}-\mathrm{Gln}-\mathrm{Glu}-\mathrm{Glu}-$ & $\beta$-Casein & \\
\hline 5 & $\mathrm{NH}_{2}$-Thr-Asp-Val-Glu-Lys- & $\beta$-Casein & Leu ${ }^{12 \pi}-T_{h} r^{128}$ \\
\hline \multicolumn{4}{|l|}{ Caprine } \\
\hline 1 & $\mathrm{NH}_{2}-\mathrm{Ty}-\mathrm{Gln}-\mathrm{Lr} s-\mathrm{Phe}-\mathrm{Ala}-$ & $\alpha_{s 2}$-Casein & $\mathrm{Tyr}^{186}-\mathrm{Tyr}^{187}$ \\
\hline 2 & $\mathrm{NH}_{2}$-Tyr-Gln-Glu-Pro-Val- & $\beta$-Casein & Leu $^{190}-\mathrm{Tyr}^{191}$ \\
\hline 3 & $\mathrm{NH}_{2}^{2}$-Trp-Net-His-Gln-Pro- & $\beta$-Casein & $\operatorname{Ser}^{142}-\operatorname{Trp}^{143}$ \\
\hline 4 & $\mathrm{NH}_{2}-\mathrm{Arg}-\mathrm{Glu}-\mathrm{Gln}-\mathrm{Glu}-\mathrm{Glu}-$ & - & - \\
\hline 5 & $\mathrm{NH}_{2}-\mathrm{Thr}-\mathrm{Asp}-\mathrm{Val}-\mathrm{Glu}-\mathrm{Lys}-$ & $\beta$-Casein & $\mathrm{Leu}^{127}-\mathrm{Thr}^{128}$ \\
\hline 6 & $\mathrm{NH}_{2}^{-}-\mathrm{Gly}-\mathrm{Glu}-\mathrm{Gln}-\mathrm{Glu}-\mathrm{Glu}-$ & - & - \\
\hline
\end{tabular}

greater than that of $\alpha_{\mathrm{s} 1}$-I-casein were visible in ovine and caprine caseinates hydrolysed for 6 and $1 \mathrm{~h}$ respectively, and were probably accounted for by fragments from $\alpha_{\mathrm{s} 1^{-}} \mathrm{I}$-casein $(\mathrm{f}(24-?))$. Three bands between $\alpha_{\mathrm{s} 1}$-I-casein and the $\mathrm{A}$ region were visible after $1 \mathrm{~h}$ hydrolysis of caprine caseinate (Fig. $1 b$ ). These may correspond to fragments of $\beta$-casein or $\beta$-I-casein. In quantitative terms, caprine $\alpha_{\mathrm{s}}$-casein was hydrolysed to a greater extent than ovine $\alpha_{\mathrm{s}}$-casein after $10 \mathrm{~h}$ incubation (Table 1).

Although caprine caseinate digestion produced more peptides than ovine caseinate digestion, their concentrations (inferred from peak areas and assuming similar response factors) were lower (Fig. 2). This may be a consequence of the different specific action of cardosin upon these two substrates. With ovine sodium caseinate, it was possible to identify four $\mathrm{N}$-terminal sequences corresponding to $\beta$-casein and one corresponding to $\alpha_{\mathrm{s} 1}$-casein (Table 2 ). One of the four $\beta$-casein peaks (peak 4 ) was the $\mathrm{N}$-terminal sequence of $\beta$-casein. With caprine sodium caseinate, two cleavage sites identified in $\beta$-casein were similar to those identified in ovine $\beta$-casein, but one additional peptide bond was cleaved (see Table 2 ). One peptide bond broken in $\alpha_{\mathrm{s} 2}$-casein was identified, but no peptide derived from $\alpha_{\mathrm{s1}}$-casein was found 
(Table 2). Two peptides could not be associated with either caprine milk casein (Table 2).

\section{DISCUSSION}

Our results were similar to those reported by cousa \& Malcata (1998) for the relative rate of hydrolysis of oxine and caprine caseinates, in that caprine caseinate was more extensively hydrolysed than ovine caseinate. Our electrophoretic profiling results for $\alpha_{s 1}$-I caxein were consistent with prerious studies using $C$. cardunculus (Sousa, 1993: Ramalho-Santos et al. 1996; Sousa \& Maleata, 1998). No $\alpha_{\mathrm{s1}}$-casein products were detected with caprine caseinate: they were probably present in low concentrations and were not resolved by the techniques employed.

The cardosin A from $C$. humilis behared as a typical aspartic proteinase. showing a preference for peptide bonds between residues with hydrophobic side chains, as previously reported for bovine caseins by Simòes (1998). This enzyme has been previously claimed (Pires ef al. 1994) to have a specific activity towards bovine caseins similar to that of cardosin A from $C$. cardunculus. Our results indicated that this claim could be extended to ovine caseinate and, to a lesser degree, to caprine caseinate.

A tentative conclusion from this study is that cardosin A from C. humilis could replace cardosin A from $C$. cardunculus in the hydrolysis of ovine caseinate.

Financial support for STS was provided by an MSe fellowship (no. BM/8824/96) issued by PRAXIS XXI (FCT. Portugal) under the joint supervision of FXM and Dr José A. Empis. Partial financial support for this work was provided by grants from the projects PROTOLACTIS: PROdução, por Tecnologias Optimizadas, de LACticínios TradicionaIS (PAMAF. Portugal) and IMPACTO : Investigação dirigida ao Melhoramento do queijo serra Por integrAçào de abordagens Científicas e TeenOlógicas (PRAXIS XXI, Portugal), both coordinated by FXM.

\section{REFERRNCES}

Axprews, A. T. 1983 Proteinases in normal bovine milk and their action on caseins, Journal of Dairy Research $5045-55$

BLAKEsLEX, R. W. \& BOEz1. J. A. 1977 A new staining technique for proteins in polyaerylamide gels using Coomassie brilliant blue G-250. Annals of Biachemistry $82580-582$

McSwenney, P. L. H., Olsox, N. F., Fox, P. F.. Hexly, A. \& Hosrup. P. 1993 Proteolytie specificity of chymosin on borine $\alpha_{\mathrm{s1}}$-casein. Josernal of Dairy Research $60401-412$

Pires, E. Faro, C.. Macedo, I., Esteves, C.. Morgado, J., Veríssimo, P.. Prefera, D. \& Gomes, D. 1994 [Cardoon flower versus chrmosin in the manufacture of traditional cheeses.] Recista da Sociedade Portaguesa de Química 54 66-68

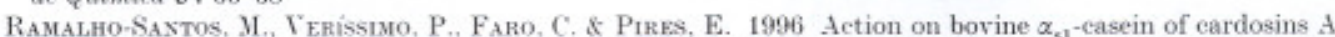
and B, aspartic proteinases from the flowers of the cardoon Cymam cardunculus L. Biochimica et Biophysica Acla $129783-89$

Roвчт, J.F. \& Whтте. B. J. 1990 Biochemical Techniques-Theory and Practice, pp. 213-252. Prospect Heights, IL: Waveland Press

Shala BI, S. I. \& Fox. P. F. 1987 Electrophoretic analysis of cheese: comparison of methods. Irish Journal of Food Science and Techuology 11 135-151

Simòrs, I. I. G. 1998 [Molecular Characterization of the Activity of Cardosins $A$ and $B$ on Bocine $\beta$ - and א-Caseins.] MSc thesis. [niversidade de Coimbra. Portuga]

Singh. T. K. Fox. P. F. \& Hexly. A. 1995 Water-soluble peptides in Cheddar eheese: isolation and identification of peptides in the diafiltration retentate of the water-soluble fraction. Journal of Dairy Research $62629-640$

Sousa. M. J. C. F. 1993 Plout Renuet Suhstitute from Floucers of Cynara carduneulus. MSe thesis, National University of Ireland. ('ork. Republic of Ireland

Sousa, M. J. \& MxLcata. F. X. 1998 Proteolysis of ovine and caprine caseins in solution by enzymatic extracts from flowers of Cynarn curdunculus, Enzyme and . Wicrobial Technology 22 305-314 


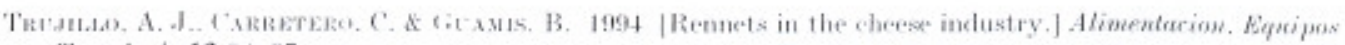
1) Teroworian $1391-97$

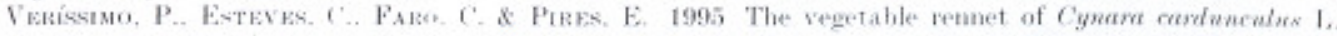
contains two proteinases with chymosin and pepsin-like specificities. Biolechoology Lellers 17 621-626

Vuand DE Si. F. \& Bxrboss. M. 1972 Cheese-making with a segetable rennet from Cardo (Cymorr

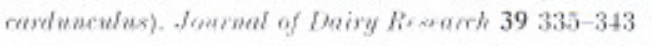

